\title{
Gene Therapy Strategy for Tumour Hypoxia
}

\author{
Hiroshi Harada \\ Group of Radiation and Tumour Biology, \\ Career-Path Promotion Unit for Young Life Scientists, \\ Kyoto University \\ Japan
}

\section{Introduction}

A characteristic feature of solid tumours is the presence of cells under very low oxygen tensions, hypoxia. These cells, so called hypoxic tumour cells, express a transcription factor, hypoxia-inducible factor 1 (HIF-1), which induces the expression of more than one hundred genes related to angiogenesis, invasion, metastasis, and resistance to conventional treatments such as chemotherapy and radiotherapy. However, because hypoxia is unique to locally advanced malignant tumours, it provides the opportunity to develop tumourspecific targeting strategies. Such an approach has been applied to gene therapy; for example, hypoxia-activated gene therapy using HIF-1-dependent promoters resulted in the selective expression of therapeutic genes and anti-tumour effects with minimum side effects in normal tissues. Here, I review recent advances in the development of cancer gene therapy strategies targeting hypoxic/HIF-1-active tumour cells.

\section{A tumour-specific microenvironment, hypoxia, as a therapeutic target}

Most human tumours are highly heterogeneous and involve diverse microenvironments. A typical microenvironment seen in solid tumours is hypoxia, low-oxygen conditions under physiological level (Thomlinson \& Gray, 1955; Vaupel, Kallinowski, \& Okunieff, 1989). Tumour hypoxia is a concern in cancer therapy because it increases the metastatic and angiogenic potential of cancer cells (Erler et al., 2006; Forsythe et al., 1996; Yang et al., 2008) and can render cancer cells resistant to radiation and chemotherapy (Brown \& Wilson, 2004; Teicher, 1994; Thomlinson \& Gray, 1955).

\subsection{What is tumour hypoxia and how does it occur in solid tumours?}

A typical feature of cancer cells is an extraordinarily accelerated proliferation caused by the activation of oncogenes and/or disruption of tumour suppressor genes (Hanahan \& Weinberg, 2000). It leads to an imbalance in the supply and consumption of $\mathrm{O}_{2}$ in a solid tumour. This disequilibrium along with the inadequate diffusion of molecular oxygen can cause a dynamic gradient of $\mathrm{O}_{2}$ content in a solid tumour (Thomlinson \& Gray, 1955; Vaupel et al., 1989). Tumour cells proliferate and grow actively only if supplied with enough oxygen and nutrients from tumour blood vessels; therefore, malignant solid tumours grow as a conglomerate of so-called "tumour cords" in each of which a blood vessel is sequentially surrounded with well-oxygenated viable cells (normoxic cells), dormant cells 
under low oxygen conditions (hypoxic cells), and dead cells (necrotic cells) Fig. 1(Hall, 1994). Because of the distance that $\mathrm{O}_{2}$ can diffuse, hypoxic cells exist $70-100 \mu \mathrm{m}$ from a tumour blood vessel in a tumour cord (Hall, 1994). Hypoxic conditions are usually defined as $<2 \% \mathrm{O}_{2}$, and anoxic conditions (severe hypoxia) as $<0.02 \% \mathrm{O}_{2}$.

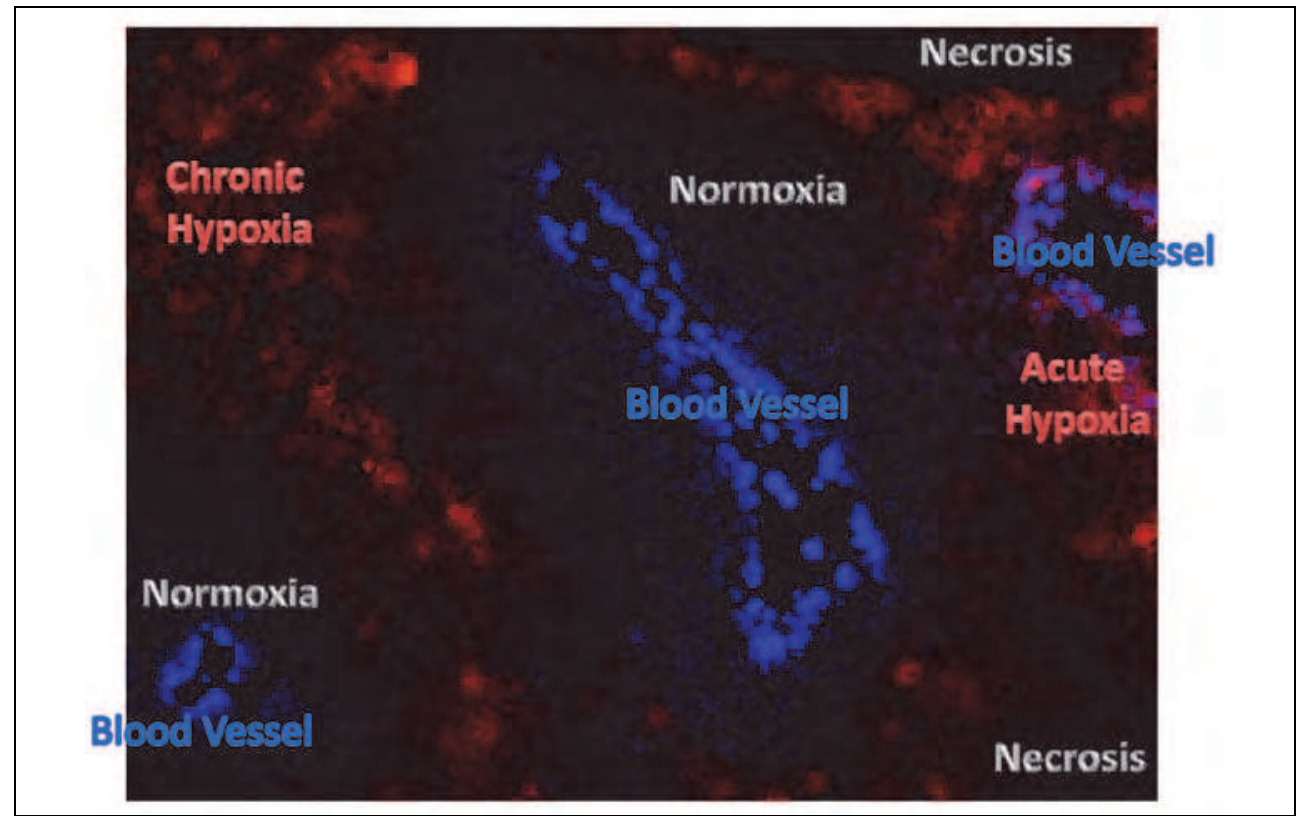

Fig. 1. Spatial relationship between blood vessels and hypoxia in a malignant solid tumour. Chronic hypoxic regions (red) exist 70-100 $\mu \mathrm{m}$ from tumour blood vessels. Acute/cycling hypoxia caused by fluctuations in tumour blood flow occurs proximal to tumour blood vessels.

In addition to areas of chronic hypoxia, malignant tumours contain cancer cells which are temporally exposed to low oxygen conditions for minutes to hours and then reoxygenated (Brown, 1979). This phenomenon, called "acute hypoxia", frequently reoccurs during tumour growth, leading to "cycling hypoxia". The occurrence of acute and cycling hypoxia is attributed to the fact that tumour blood vessels are quite immature and tortuous; and therefore, tumour blood flow fluctuates dramatically during tumour growth (Brown \& Wilson, 2004).

\subsection{Chemo-resistance of cancer cells under hypoxic conditions}

Cancer cells are known to become chemo-resistant in hypoxic regions of locally advanced solid tumours through multiple mechanisms (Kizaka-Kondoh, Inoue, Harada, \& Hiraoka, 2003; Teicher, 1994). First, because hypoxic regions occur far from functional vasculatures, the diffusion and delivery of most anticancer drugs are not extensive enough to have a cytotoxic effect (Durand, 1994; Hicks et al., 2006; Tannock, 1998). Second, the cytotoxicity of some anticancer drugs is known to depend on molecular oxygen. For example, bleomycin is reported to chelate metal ions, produce a pseudoenzyme that reacts with oxygen and 
generates superoxide and hydroxide free radicals, and then cleave DNA. Therefore, the cytotoxic effect of the drug dramatically decreases in the absence of $\mathrm{O}_{2}$ (Batchelder, Wilson, Hay, \& Denny, 1996; Teicher, Lazo, \& Sartorelli, 1981). Third, alkylating agents and antimetabolites are also less effective under hypoxic conditions. These kinds of drugs are the most effective against highly proliferating cancer cells, and therefore, hypoxic tumour cells, which are known to be dormant/less proliferating, can tolerate them (Tannock, 1968). Fourth, hypoxia upregulates the expression of genes involved in drug resistance, including the gene for p-glycoprotein (Comerford et al., 2002; Wartenberg et al., 2003). Finally, there is evidence that hypoxia can enhance genetic instability in tumour cells (N. Chan et al., 2008), thus allowing a more rapid development of drug resistance.

\subsection{Radio-resistance of cancer cells under hypoxic conditions}

Ionizing radiation produces DNA damage, such as DNA double/single strand breaks, DNA base damage, and DNA-DNA and DNA-protein crosslinks (Hall, 1994). The presence or absence of molecular oxygen influences the damage and death of cancer cells (Brown \& Wilson, 2004; Thomlinson \& Gray, 1955). This phenomenon, the so-called oxygen effect, was first identified in 1912 with the observation that the skin reaction to a radium applicator dramatically decreased when the applicator was pushed tightly onto the skin and consequently decreased blood flow there. The breakthrough linking the effect of oxygen with radioresistance of cancer cells was made by Thomlinson and Gray in 1955 (Thomlinson \& Gray, 1955). They proposed that oxygen levels decreased in a solid tumour through successive layers of cancer cells distal to blood vessels, and cancer cells a distance of about 10 cell diameters from vessels are viable but radioresistant. Actually, cancer cells become 2-3 times more radioresistant under hypoxic conditions than normoxic conditions (Brown \& Wilson, 2004).

The hypoxia-mediated radioresistance is attributed to both chemical and biological mechanisms. Ionizing radiation induces ionization in or close to the genomic DNA of target cells and produces radicals (Brown \& Wilson, 2004). The DNA radicals are subjected to oxidation in the presence of oxygen, leading to fixation of the damage. In the absence of oxygen, however, the DNA radicals are reduced by compounds containing sulfhydryl groups (SH groups), which restore the DNA to its original form. Therefore, DNA damage, especially irreparable double stranded breaks, is significantly less severe in the absence of molecular oxygen. Biological mechanisms are also important. It has been elucidated that hypoxic stimuli trigger changes in both the "DNA damage repair pathway" (Bindra, Crosby, \& Glazer, 2007) and the "cell death/survival signaling pathway". Moreover, recent advances in molecular and cellular biology revealed an important role for a transcription factor, hypoxia-inducible factor 1 (HIF-1), in tumour radioresistance (see Section 3 for details) (Harada \& Hiraoka, 2010).

\subsection{Increase in metastatic and angiogenic potential under hypoxic conditions}

In addition to mediating resistance to conventional treatments, hypoxia is known to increase the metastatic and angiogenic potential of tumour cells. Cancer patients with relatively more hypoxic regions have a tendency to suffer from distant metastasis as well as local recurrence regardless of whether the initial treatment is surgery or radiation therapy (Brizel et al., 1996). Recent molecular biological analyses have revealed that hypoxia stimulates the expression of a number of genes involved in metastatic cascades, such as lysyl oxidase and the chemokine receptor, CXCR4, osteopoetin (D. A. Chan \& Giaccia, 2007; Erler et al., 2006; 
Rofstad, 2000). Also, cancer cells under hypoxic conditions trigger angiogenesis in order to improve surrounding conditions and obtain enough oxygen and nutrients for their survival (Folkman, 1971). HIF-1 is known to play a pivotal role in the hypoxia-mediated increase in both the metastatic and angiogenic potential of cancer cells.

\section{Hypoxia-inducible factor 1 (HIF-1)}

Molecular and cellular biological research has identified HIF-1 as an important transcription factor in hypoxia-mediated angiogenesis, metastasis, and resistance to chemo/radiotherapy.

\subsection{Regulation of HIF-1 expression and activity}

HIF-1 is a heterodimeric transcription factor composed of alpha (HIF-1 $\alpha$ ) and beta (HIF$1 \beta /$ ARNT) subunits (Wang, Jiang, Rue, \& Semenza, 1995). Its hypoxia-dependent activity is mainly regulated through the stabilization and modification of the HIF-1 $\alpha$ subunit (Fig. 2).

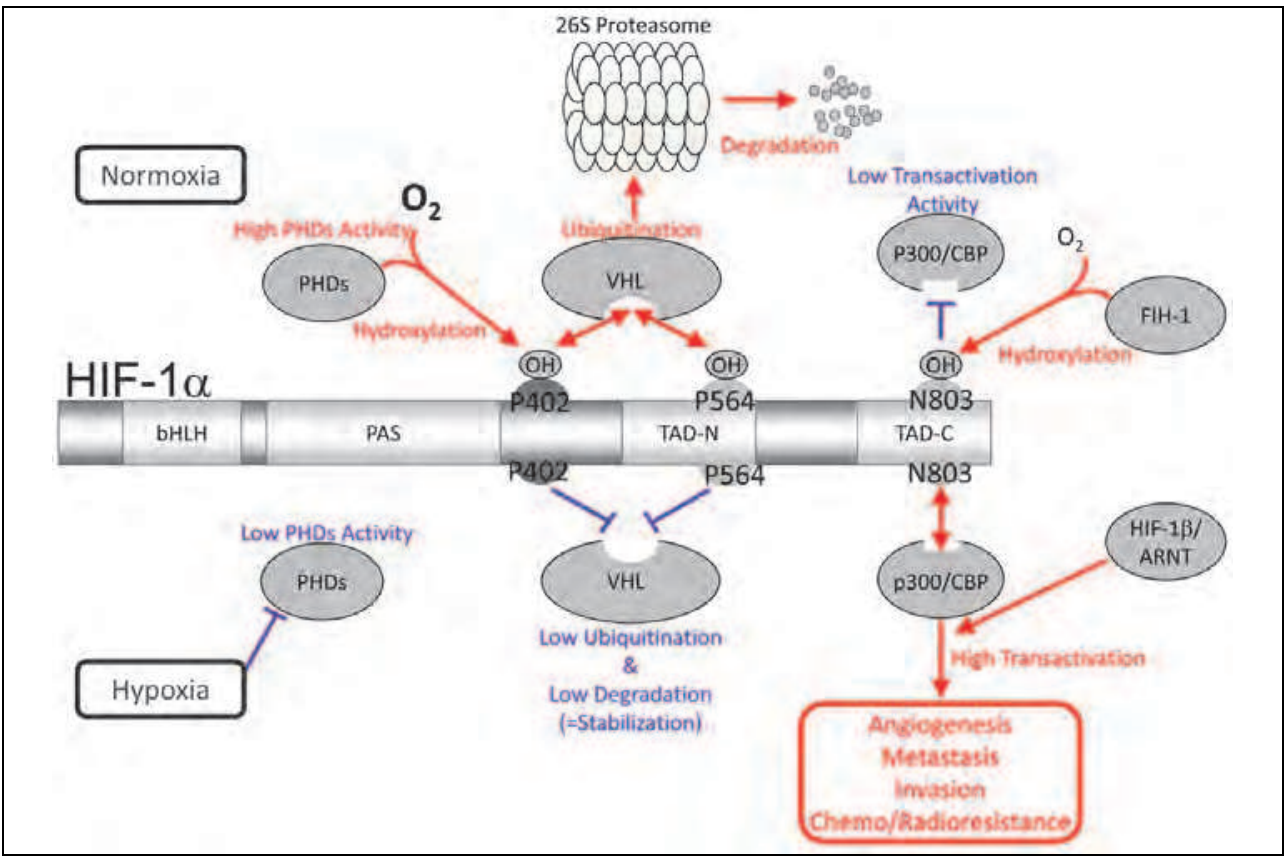

Fig. 2. Molecular mechanism behind the activation of HIF-1 under Hypoxic conditions.

The best-characterized regulatory mechanism is that modulating HIF- $1 \alpha$ 's stability. Under well-oxygenated normoxic conditions, prolyl hydroxylation (by prolyl hydroxylases [PHDs]) and subsequent ubiquitination (by von-Hippel Lindau (VHL)-containing E3 ubiquitin-protein ligase) of the oxygen-dependent degradation (ODD) domain of HIF-1 $\alpha$ leads to rapid degradation of HIF-1 $\alpha$ with a half life of 5-8 min. Consequently, HIF-1 is inactive under normoxic conditions (Berra, Roux, Richard, \& Pouyssegur, 2001; Hirota \& Semenza, 2005; Jaakkola et al., 2001; Maxwell et al., 1999; Semenza, 2001). On the other hand, under oxygen-deprived hypoxic conditions, HIF-1 $\alpha$ becomes stable because oxygen- 
depletion directly decreases the PHDs' activity (Jaakkola et al., 2001). Then, HIF-1 $\alpha$ interacts with HIF-1 $\beta$, forms a heterodimer, HIF-1 (Wang et al., 1995), binds to its cognate DNA sequence, the hypoxic-responsive element (HRE), and finally induces the expression of various genes related to angiogenesis, metastasis, glycolysis and so on (D. A. Chan \& Giaccia, 2007; Erler et al., 2006; Forsythe et al., 1996; Kim, Gao, \& Dang, 2007; Rofstad, 2000). In addition to the regulation of HIF-1 $\alpha$ 's stability, another post-translational modification of HIF- $1 \alpha$ is known to function in the regulation of the transactivational activity of HIF-1. Under normoxic conditions, factor inhibiting HIF-1 (FIH-1) becomes active and hydroxylates an asparagine residue (N803) of HIF-1 $\alpha$ (Hirota \& Semenza, 2005; Mahon, Hirota, \& Semenza, 2001; Semenza, 2001). The asparaginyl hydroxylation blocks the interaction of HIF- $1 \alpha$ with the transcriptional co-factor p300 and CBP, resulting in the suppression of HIF-1's transactivational activity. Because oxygen is a substrate of FIH-1 as well as PHDs, HIF-1's transactivational activity is restored under oxygen-deprived hypoxic conditions.

\subsection{Function of HIF-1 in cancer cells}

In cancer cells, HIF-1 plays pivotal roles in the adaptation to (metabolic reprograming), evasion from (invasion and metastasis), and improvement of (angiogenesis) severe hypoxic conditions (D. A. Chan \& Giaccia, 2007; Erler et al., 2006; Forsythe et al., 1996; Semenza, 2007, 2008). Concerning angiogenesis in locally advanced malignant tumours, an upregulation of HIF-1 activity caused by intratumoural hypoxia is associated with the overexpression of vascular endothelial growth factor (VEGF), a glycoprotein responsible for angiogenesis and vasculogenesis (Forsythe et al., 1996). Concerning the metabolic reprogramming of cancer cells, HIF-1 induces the expression of genes encoding glucose transporters and glycolytic enzymes to facilitate glycolysis (Semenza, 2009; Wood et al., 1998). At the same time, HIF-1-dependent genes decrease both mitochondrial metabolism (Fukuda et al., 2007; Semenza, 2007) and mitochondrial mass (Semenza, 2008; H. Zhang et al., 2008). These functions of HIF-1 are responsible for both the efficient production of ATP even under oxygen-deprived conditions and the decrease in the cytotoxic reactive oxygen species (ROS) produced through incomplete oxidative phosphorylation under hypoxic conditions (Fukuda et al., 2007; Semenza, 2007, 2009). Concerning invasion and metastasis, HIF-1 is known to trigger various pathways including epithelial-mesenchymal transition (EMT) and expression of the Met protooncogene and lysyl oxidase, which function in tumour metastasis (Erler et al., 2006; Pennacchietti et al., 2003).

\subsection{Function of HIF-1 in tumour radioresistance}

Preclinical studies have found that inhibition of intratumour HIF-1 activity by a pharmacological HIF-1 inhibitor, YC-1, or by a dominant negative mutant of HIF-1 $\alpha$ and the knockdown of HIF-1 $\alpha$ expression by short hairpin RNA or short interfering RNA significantly delayed tumour growth after radiation (Harada et al., 2009; Moeller, Cao, Li, \& Dewhirst, 2004; Moeller et al., 2005; X. Zhang et al., 2004). It was also confirmed through clinical studies that HIF- $1 \alpha$ expression correlates with a poor prognosis after radiation therapy (Aebersold et al., 2001; Irie, Matsuo, \& Nagata, 2004; Ishikawa et al., 2004). These results imply that HIF-1 has a certain biological function to increase tumour radioresistance. Actually, HIF-1-mediated radioresistance has been recently revealed: 1) radiation activates HIF-1 in a solid tumour, 2) HIF-1 induces the expression of VEGF, 3) VEGF protects endothelial cells from the cytotoxic effects of radiation, and 4) the radio-protected tumour 
blood vessels assure the supply of oxygen and nutrients to tumour cells and promote tumour growth (Harada et al., 2009; Moeller et al., 2004; Zeng et al., 2008).

\section{Development of gene therapy strategies targeting tumour hypoxia}

Because hypoxic/HIF-1-active cells are known to mediate tumour malignancy and resistance to conventional treatments, and because hypoxia has been recognized as a tumour-specific microenvironment, recent studies have tried to exploit hypoxic cells as targets for cancer therapy (Brown \& Wilson, 2004; Harris, 2002; Semenza, 2003). Dachs et al. were the first to apply this concept to gene therapy (Dachs, Patterson, et al., 1997). Since they demonstrated the effectiveness of hypoxia-specific gene therapy strategy using the HIF-1/HRE system, extensive efforts have been devoted to developing genetically engineered hypoxia-responsive promoters.

\subsection{Development of HIF-1-dependent promoters}

Various HREs, such as murin phosphoglycerate kinase-1 (PGK-1) HRE, human enolase (ENO) HRE, murin lactate dehydrogenase (mLDH-A) HRE, human erythropoietin (EPO) HRE, and human VEGF HRE, have been used to develop artificial hypoxia-responsive promoters (Table 1) (Binley, Iqball, Kingsman, Kingsman, \& Naylor, 1999; Boast et al., 1999; Dachs, Patterson, et al., 1997; Harada et al., 2007; Rinsch et al., 1997; Shibata, Akiyama, Noda, Sasai, \& Hiraoka, 1998; Shibata, Giaccia, \& Brown, 2000). The number of HREs and combination with the basal promoter influence the hypoxia/HIF-1-responsiveness of each HRE-containing promoter (Table 1).

Above all, the combination of five repeats of a HRE derived from the human VEGF promoter and the human cytomegarovirus (CMV) minimal promoter (mp), the so-called "the 5HRE promoter", showed intense hypoxia-responsiveness and exhibited a more than 500 -fold increase in luciferase activity in response to hypoxic stimuli (Shibata et al., 2000). Moreover, the absolute level of luciferase activity from the 5HRE promoter under hypoxic conditions reached the same level as that from the constitutively active CMV-driven promoter under normoxic conditions (Shibata et al., 2000).

However, the 5HRE promoter still has problems relating to the development of gene therapy. It shows a certain level of unwanted gene expression even when oxygen is available under normoxic conditions (Harada et al., 2007), which would cause high basal expression of therapeutic genes and result in side effects in well-oxygenated normal tissues. In order to decrease leakage under normoxic conditions, I and my colleagues came up with the idea of utilizing the ODD domain of HIF- $1 \alpha$. We fused the coding sequence of the ODD domain to that of luciferase, and inserted the fusion gene downstream of the 5HRE promoter. The resultant 5HREp-ODD-luc gene showed little leakage under normoxic conditions. Leakage from the conventional 5HREp-luc gene was $1.4 \times 10^{3}$ (arbitary units), on the other hand, that from the novel 5HREp-ODD-luc gene was just $1.5 \times 10^{1}$ (arbitary units), almost the same as the background level. Moreover, the oxygen-dependent destabilizing effect of the ODD domain contributed to an increase in the hypoxia-responsiveness to about $4.7 \times 10^{4}$.

The potential of hypoxia/HIF-1-dependent promoters in vivo has been proved through immunohistochemical analyses and optical imaging experiments. The human melanoma cell line, Be11, was stably transfected with a plasmid expressing a derivative of EGFP, d2EGFP, under the control of the 5HRE promoter, and transplanted into immunodeficient nude mice 


\begin{tabular}{|c|c|c|c|c|}
\hline HRE & Basal Promoter & Reporter Gene & Induction Ratio & References \\
\hline $3 \times$ mPGK-1 & mPGK-1 & $\mathrm{CD} 2$ & $1.4-1.9$ & \multirow{3}{*}{ Dachs, 1997} \\
\hline $3 \times \mathrm{mPGK}-1$ & minHSV TK & CD2 & $2.2-2.33$ & \\
\hline $3 \times$ mPGK-1 & 9-27 gene & $\mathrm{CD} 2$ & $2.2-4.1$ & \\
\hline mPGK-1 & mPGK-1 & $\mathrm{hEPO}$ & 2.7 & Rinsch, 1997 \\
\hline hVEGF & hVEGF & luciferase & $3.3-8.5$ & \multirow{4}{*}{ Shibata, 1998} \\
\hline hEPO & SV40 & luciferase & $2-5$ & \\
\hline $5 \times \mathrm{hVEGF}$ & hVEGF & luciferase & 20 & \\
\hline $5 \times \mathrm{hVEGF}$ & $\begin{array}{l}\text { hVEGF+ } \\
\text { minE1b }\end{array}$ & luciferase & 44 & \\
\hline $3 \times$ hENO & SV40 & luciferase & 120 & \multirow{7}{*}{ Boast, 1999} \\
\hline $3 \times$ hENO & SV40 & luciferase & 63 & \\
\hline $2 \times \mathrm{mLDHA}$ & SV40 & luciferase & 81 & \\
\hline $4 \times$ mLDHA & SV40 & luciferase & 65 & \\
\hline $4 \times \mathrm{hEPO}$ & SV40 & luciferase & 255 & \\
\hline $3 \times$ hENO & SV40 & luciferase & 146 & \\
\hline $\begin{array}{l}3 \times \text { mPGK-1+ } \\
\text { VEGF 3' UTR }\end{array}$ & SV40 & luciferase & 300 & \\
\hline mPGK-1 & SV40 & $\beta$-gal & $8.5-50$ & Binley, 1999 \\
\hline 5 or $10 \times$ hVEGF & SV40 & luciferase & $54-57$ & \multirow{6}{*}{ Shibata, 2000} \\
\hline $\begin{array}{l}5 \text { or } 10 \times \text { hVEGF+ } \\
5^{\prime} \text { VEGF UTR }\end{array}$ & SV40 & luciferase & $23-27$ & \\
\hline $\begin{array}{l}\text { 5-10 × hVEGF+ } \\
\text { 5' VEGF UTR }\end{array}$ & E1b & luciferase & $56-60$ & \\
\hline $\begin{array}{c}5 \times \text { hVEGF+ } \\
5^{\prime} \text { VEGF UTR } \\
5 \times \text { hVEGF+ }\end{array}$ & E1b & luciferase & 131 & \\
\hline $\begin{array}{l}\text { 5' VEGF UTR+ } \\
\text { 3' VEGF UTR }\end{array}$ & E1b & luciferase & 193 & \\
\hline $5 \times$ hVEGF & hCMV-mp & luciferase & 524 & \\
\hline $5 \times$ hVEGF & hCMV-mp & luciferase & 47,000 & Harada, 2007 \\
\hline
\end{tabular}

Table 1. Genetically engineered hypoxia-responsive promoters.

(Liu et al., 2005). Resultant tumour xenografts showed heterogeneous, partition-dependent and weak green fluorescence. Immunohistochemical analyses confirmed that d2EGFPpositive cells were located at the boundary between well-oxygenated viable regions and necrotic regions, which were stained with a hypoxia marker, pimonidazole (Raleigh et al., 1998). When human cervical cancer cells, HeLa cells, transfected with the 5HREp-luc or $5 H R E p-O D D-l u c$ gene were transplanted into nude mice, the resultant xenografts showed intense bioluminescence after the tumour-bearing leg was ligated and the blood flow to the xenograft decreased (Harada, Kizaka-Kondoh, \& Hiraoka, 2005; Harada et al., 2007).

\subsection{Hypoxia-targeted gene-directed enzyme/prodrug therapy using a HIF-1-dependent promoter}

To exploit tumour hypoxia/HIF-1 active cells as a tumour-specific therapeutic target, several approaches have been examined including (1) hypoxia-targeting using hypoxia/HIF-1-responsive promoters combined with Gene-Directed Enzyme Prodrug 
Therapies (GDEPT) (Greco, Marples, Joiner, \& Scott, 2003; Liu, Harada, Ogura, Shibata, \& Hiraoka, 2007; Ogura et al., 2005; Patterson et al., 2002; Shibata, Giaccia, \& Brown, 2002), and (2) hypoxia-specific replication of adenovirus (Hernandez-Alcoceba, Pihalja, Qian, \& Clarke, 2002; Post \& Van Meir, 2003) (Table 2).

\begin{tabular}{|c|c|c|c|}
\hline Delivery System & Hypoxia-specific Strategy & Result & Reference \\
\hline $\begin{array}{l}\text { NA (Transfected } \\
\text { cancer cell line) }\end{array}$ & $\begin{array}{l}\text { GDEPT: } 5 \times \text { VEGF-HRE- } \\
\text { containing promoter driven NTR } \\
\text { gene expression in HT1080 cells } \\
\text { and i.p. injection of the anticancer } \\
\text { prodrug CB1954. }\end{array}$ & $\begin{array}{l}\text { Significant } \\
\text { tumour growth } \\
\text { delay }\end{array}$ & Shibata, 2002 \\
\hline $\begin{array}{l}\text { NA (Transfected } \\
\text { cancer cell line) }\end{array}$ & $\begin{array}{l}\text { GDEPT: } 5 \times \text { VEGF-HRE- } \\
\text { containing promoter-driven HSV- } \\
\text { TK gene expression and i.p. } \\
\text { injection of GCV }\end{array}$ & $\begin{array}{l}\text { Tumour growth } \\
\text { suppression }\end{array}$ & Ogura, 2005 \\
\hline $\begin{array}{l}\text { NA (Transfected } \\
\text { cancer cell line) }\end{array}$ & $\begin{array}{l}\text { GDEPT: PGK-1 HRE/SV40 } \\
\text { chimeric promoter-driven P450R } \\
\text { gene expression and i.p. injection } \\
\text { of the 2-nitroimidazole } \\
\text { bioreductive prodrug, RB6145 }\end{array}$ & $\begin{array}{c}\text { Enhanced } \\
\text { Radiotherapy }\end{array}$ & Patterson, 2002 \\
\hline Adenovirus & $\begin{array}{l}\text { GDEPT: optimized hypoxia } \\
\text { response promoter using PGK-1 } \\
\text { HRE-driven human cytochrome } \\
\text { P450 (CYP2B6) gene expression } \\
\text { and i.p. injection of } \\
\text { cyclophosphamide }\end{array}$ & $\begin{array}{l}\text { Delay in tumour } \\
\text { growth }\end{array}$ & Binley, 2003 \\
\hline Adenovirus & $\begin{array}{l}\text { 3XHRE/5XERE-regulated E1A } \\
\text { expression and hTERT (AdEHT2) } \\
\text { or E2F-1 (AdEHE2F) promoter- } \\
\text { regulated E4 expression. }\end{array}$ & $\begin{array}{l}\text { Tumour growth } \\
\text { suppression and } \\
\text { regression }\end{array}$ & $\begin{array}{l}\text { Hernandez- } \\
\text { Alcoceba, } 2002\end{array}$ \\
\hline $\begin{array}{l}\text { Adenovirus } \\
\text { (intratumoural } \\
\text { injection) }\end{array}$ & $\begin{array}{l}\text { GDEPT: } 5 \text { x VEGF-HRE- } \\
\text { containing promoter-driven } \\
\text { bacterial cytosine deaminase } \\
\text { (BCD) gene expression and i.p. } \\
\text { injection of 5-FC. }\end{array}$ & $\begin{array}{l}\text { Tumour growth } \\
\text { suppression and } \\
\text { enhanced } \\
\text { radiotherpy }\end{array}$ & Liu, 2007 \\
\hline Adenovirus & $\begin{array}{c}\text { human VEGF promoter-driven } \\
\text { BAX gene expression }\end{array}$ & $\begin{array}{l}\text { induction of } \\
\text { apoptosis and } \\
\text { suppression of } \\
\text { cell growth in } \\
\text { vitro }\end{array}$ & Kaliberov, 2002 \\
\hline
\end{tabular}

Table 2. Gene therapy strategies for tumour hypoxia examined so far.

NA, not applicable; HSV-TK, the herpes simplex virus thymidine kinase; GCV, ganciclovir; GDEPT, Gene-Directed Enzyme Pordrug Therapy; NTR, nitroreductase; CRAD, conditionally replicative adenoviruses; ER, estrogen receptor; ERE, estrogen response element; hTERT, human telomerase reverse transcriptase; CD, cytosine deaminase; VEGF, Vascular Endthelial Growth Factor, 5-FU, 5-fluorouracil; 5-FC, 5-flucytosine; 


\subsubsection{Gene-directed enzyme prodrug therapy (GDEPT) with HIF-1-dependent promoters}

GDEPT involves the delivery to target cells of a foreign gene, which is non-toxic but activates prodrugs to toxic agents and induces anti-tumour effects (Fig. 3 Dachs, Dougherty, Stratford, \& Chaplin, 1997; Greco et al., 2003). HIF-1 activity is detected at high levels in hypoxic tumour cells but generally not in normal tissues as mentioned above; therefore, HIF-1-dependent promoters provide a chance to accomplish tumour-specific GDEPT. The target-specificity and therapeutic effects of GDEPT with HIF-1-dpendent promoters have been examined in experimental tumour systems either by administering viral vectors (Binley et al., 2003; Liu et al., 2007) or by using unique tumour xenografts prepared by transplanting cancer cells which express a prodrug-activating enzyme under the control of a HIF-1-dependent promoter (Ogura et al., 2005; Patterson et al., 2002; Shibata et al., 2002). Examples of enzyme/prodrug combinations in GDEPT are the bacterial nitroreductase (NTR)/anticancer prodrug CB1954, the cytochrome P450 reductase (P450R)/RSU1069, the herpes simplex virus thymidine kinase (HSV-TK)/ganciclovir (GCV), and the bacterial cytosine deaminase (BCD)/anti-herpes viral agent 5- fluorocytosine (5-FC).

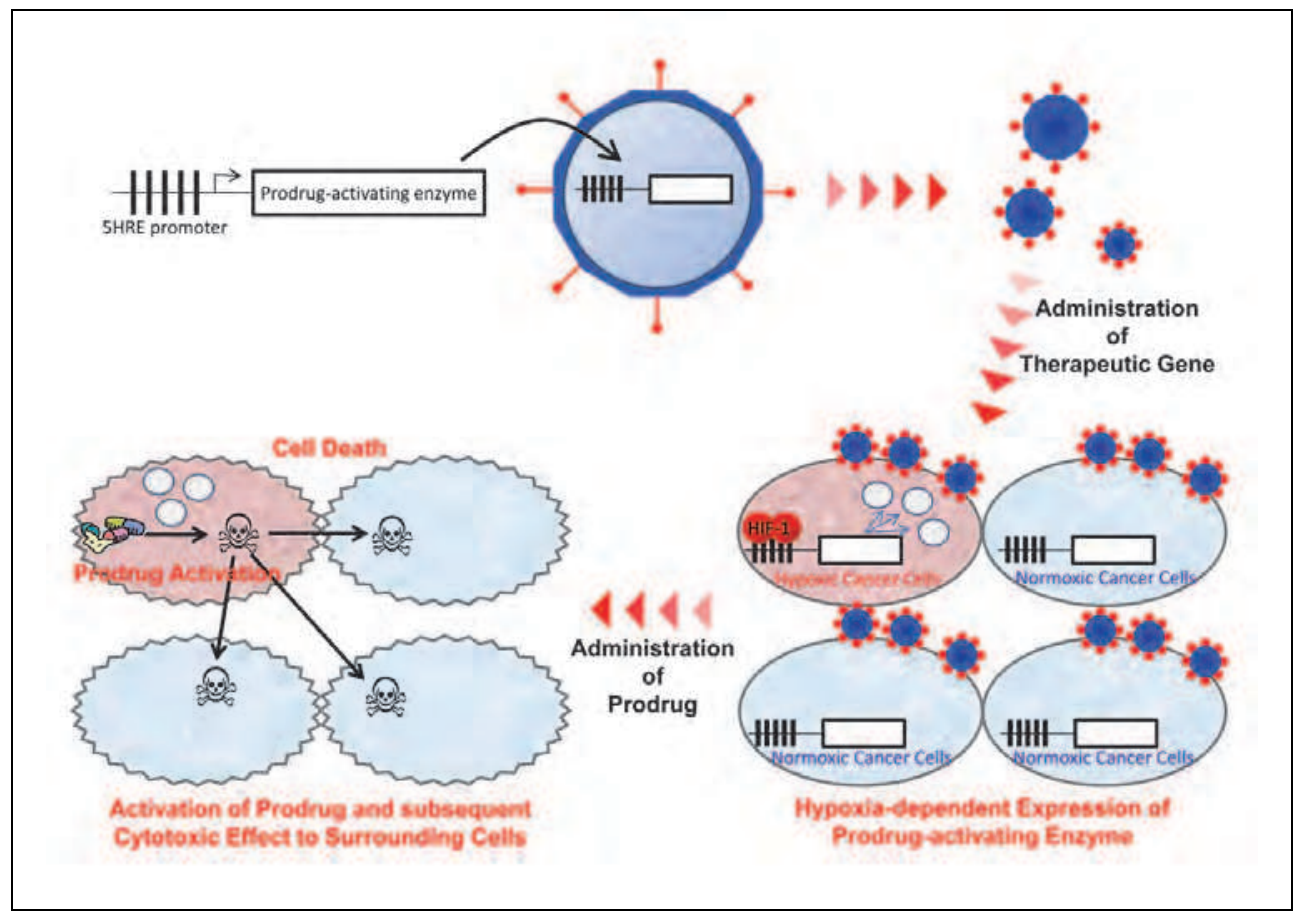

Fig. 3. Concept of GDEPT targeting tumour hypoxia.

Using HREs derived from the VEGF promoter, Shibata et al. generated vectors expressing a bacterial NTR gene in a HIF-1-dependent manner, and established stable transfectants of a human fibrosarcoma cell line, HT1080 (Shibata et al., 2002). Hypoxia-induced expression of the NTR protein correlated with increased sensitivity of HT1080 cells to the prodrug CB1954 (Shibata et al., 2002). Growth delay assays with established tumour xenografts derived from 
the same cells showed that significant antitumour effects were achieved with intraperitoneal injections of CB1954 (Shibata et al., 2002). In addition, respiration of $10 \% \mathrm{O}_{2}$ increased the hypoxic fraction in the tumour xenograft in vivo and enhanced the antitumour effects (Shibata et al., 2002).

A one-electron reductase, such as P450R, can be used for prodrug-activation. Patterson et al. reported that selective hypoxia-targeting could be accomplished by using an optimized PGK-1 HRE/SV40 chimeric promoter to regulate the expression of P450R. HT1080 cells stably transfected with the gene produced a 3.4-fold increase in P450R activity as a result of anoxic incubation, leading to a 30 -fold enhancement of the cytotoxicity of the 2nitroimidazole bioreductive prodrug, RSU1069 (Patterson et al., 2002).

As for HSV-TK/GCV gene therapy, Ogura et al. demonstrated that promoters containing 5 copies of the VEGF HRE assured the expression of the HSV-TK gene in a HIF-active renal cell carcinoma, resulting in GCV-dependent tumour growth suppression (Ogura et al., 2005). An important point of their study is that HIF-dependent HSV-TK/GCV gene therapy can target not only hypoxic but also normoxic renal cell carcinoma (RCC) cells because the VHL gene, which triggers the destruction of HIF-1a and HIF-2a during normoxia, is inactive in $33-57 \%$ of sporadic clear-cell RCCs, which accounts for $75 \%$ of RCCs.

Binley et al. used an optimized hypoxia-responsive promoter (OBHRE) with the PGK-1 HRE and investigated hypoxia-targeted gene expression in vivo in the context of an adenoviral vector (Binley et al., 2003). The OBHRE promoter showed limited activity in the liver or spleen such that expression was 1000 -fold lower than that driven by the strong CMV/IE promoter (Binley et al., 2003). However, in the context of the tumour microenvironment, the OBHRE promoter achieved expression levels comparable to that of the CMV/IE promoter. Moreover, they showed that an adenovirus expressing the human cytochrome P450 (CYP2B6) regulated by the OBHRE promoter delays tumour growth in response to the prodrug cyclophosphamide (CPA) (Binley et al., 2003).

As for CD/5-FC gene therapy, Liu et al. constructed an adenoviral vector in which the 5HRE promoter was responsible for the HIF-1-dependent expression of CD (Liu et al., 2007). Administration of the adenovirus resulted in the expression of $C D$ in hypoxic regions of solid tumours, leading to 5- FC-dependent tumour growth suppression and enhancement of the therapeutic effect of radiation therapy (See Section 4.4 for details about the radioenhancing effect).

In general, GDEPT is thought to have two advantages: amplification of its therapeutic effect and a bystander therapeutic effect. The former is due to the ability of each prodrugactivating enzyme to activate a number of prodrug molecules. The latter advantage results from an extension of the killing effects of the activated/converted drug to surrounding cancer cells, which don't express the therapeutic gene and don't convert the prodrug to the active anticancer drug. Therefore, even if systemic delivery of the therapeutic genes is not effective Fig. 3, tumour eradication may still be achieved.

\subsubsection{Other gene therapy strategies targeting tumour hypoixia}

\subsubsection{Gene therapy using a cytotoxic gene and HIF-1-dependent promoter}

An alternative GDEPT uses cytotoxic proteins instead of prodrug-activating enzymes expressed in a HIF-1-dependent manner (Table 2). Kaliberov et al. prepared an adenovirus, AdVEGFBAX, which expressed an inducer of apoptosis, BAX, under the control of a VEGF promoter (Kaliberov et al., 2002). They confirmed the potential therapeutic application of VEGF promoter-driven cancer-specific expression of the pro-apoptotic Bax gene. 


\subsubsection{Gene therapy using a hypoxia/HIF-dependent oncolytic adenovirus}

The lytic cycle of adenoviruses is known to result in the death of infected cells, and thus this property has been exploited as a therapeutic strategy against cancer. Post and Van Meir have developed a hypoxia/HIF-dependent replicative adenovirus (HYPR-Ad) that exhibits HIF-1-dependent E1A expression and conditional cytolysis of hypoxic cells but not normoxic cells (Post \& Van Meir, 2003). This is the first evidence that an attenuated oncolytic adenovirus that selectively lyses hypoxic tumour cells can be generated.

\subsection{Side effect of hypoxia-targeting gene therapies}

To measure the damage to normal tissue after gene therapy targeting tumour hypoxia, Binley et al. evaluated the activity of lactate dehydrogenase (LDH) as an indicator of liver dysfunction after their hypoxia-responsive thymidine kinase/ganciclovir (TK/GCV) suicide gene therapy (Binley et al., 2003). Hypoxia-dependent TK expression and subsequent GCV treatment caused no irregularity in LDH levels. On the other hand, constitutive TK expression from a CMV promoter and GCV treatment significantly elevated LDH levels in mice. These results suggest that a hypoxia-responsive promoter would facilitate target specificity and so reduce the side effects on well-oxygenated normal tissues, meaning an increased therapeutic window for cytotoxic cancer gene therapies.

Liu et al observed no obvious side effects after hypoxia-targeting gene therapy with a 5HRE promoter-mediated BCD/5-FC strategy (Liu et al., 2007). On the other hand, after the $\mathrm{Ad} / \mathrm{EFp}-\mathrm{BCD} / 5-\mathrm{FC}$ treatment, which constitutively expresses BCD regardless of surrounding oxygen conditions, they observed significant weight loss and severe diarrhea (Liu et al., 2007). These results strengthen the argument that we can exploit tumour hypoxia as a tumour-specific target of cancer gene therapy, and that hypoxia/HIF-1-dependent therapeutic gene expression helps to avoid side effects in normal tissues.

\subsection{Improvement of the effect of radiotherapy by hypoxia/HIF-1-targeting gene therapies}

As tumour hypoxia and HIF-1 activity are responsible for tumour radioresistance (Aebersold et al., 2001; Harada et al., 2009; Irie et al., 2004; Ishikawa et al., 2004; Moeller et al., 2004; Moeller et al., 2005; X. Zhang et al., 2004), the specific targeting of tumour hypoxia and/or HIF-1 activity by gene therapy strategies may improve the efficacy of radiotherapy. Actually, Patterson et al. demonstrated that the therapeutic effect of radiation can be enhanced by a hypoxia-targeting gene therapy strategy (Patterson et al., 2002). They transfected HT1080 cells with a hypoxia-regulated expression vector encoding the human P450 reductase (HRE-P450R). Xenografts of HRE-P450R and empty vector transfectants had comparable hypoxic fractions and were refractive to a single dose of radiotherapy of up to 15 Gy. However, combining a prodrug RSU1069 with a reduced dose of radiotherapy (10 Gy) cured $50 \%$ of mice bearing HRE-P450R xenografts by 100 days after the treatment. On the other hand, one hundred percent mortality was observed by day 44 in the empty vector control xenografts treated using the same protocol.

Liu et al. treated HeLa tumour xenografts with adenovirus-mediated hypoxia-targeting cytosine deaminase gene therapy (Ad/5HREp-BCD/5-FC) and/or radiotherapy (IR), and carried out growth delay assays (Liu et al., 2007). They intentionally chose a low dose of $\mathrm{Ad} / 5 \mathrm{HREp}-\mathrm{BCD} / 5-\mathrm{FC}$, which had minimal effects on the tumour growth rate compared to that after sham-treatment. Combined with IR, the gene therapy strikingly suppressed tumour growth as compared to radiotherapy alone. The period taken for tumour growth to 
increase two-fold from the initial volume (tumour growth doubling time: TGDT) was $13.2 \pm$ 5.6 days after gene therapy alone, which is not significantly longer than that after shamtreatment $(8.2 \pm 3.1$ days). On the other hand, the combination of gene therapy with radiotherapy prolonged the TGDT to $47.2 \pm 16.8$ days, which was about 2.4 -fold longer than that after radiotherapy alone $(19.4 \pm 4.8$ days). Similar results were observed after fractionated irradiation ( $3 \mathrm{~Gy} \times 5$ fractions). The TGDT after gene therapy alone was $13.0 \pm$ 4.4 days, which is not significantly longer than that after sham treatment (9.8 \pm 5.8 days). On the other hand, the TGDT after the fractionated radiotherapy was $17.0 \pm 3.7$ days, which was significantly delayed by the combination with the gene therapy to $43.3 \pm 23.8$ days. These results also lead to a conclusion that hypoxia-targeting gene therapy combined with radiotherapy is a promising approach to cancer treatment.

\section{Conclusion}

Cancer cells under hypoxic conditions/HIF-1-active cancer cells have been recognized as crucial and excellent targets for cancer therapy not only because they mediate tumour malignancy and resistance to conventional treatments but also because they are only seen in malignant tumours, not in normal tissues. Several approaches have been used to target these cell populations; hypoxia-targeting using hypoxia-responsive promoters combined with GDEPT, and hypoxia-specific replication of adenovirus as well as hypoxic cytotoxins and HIF-1 inhibitors. Hypoxia/HIF-1-targeting gene therapy is a promising tumour-specific approach with few side effects in normal tissues, and has the potential to enhance the effect of radiation therapy. Some approaches are now in clinical trials and are expected to lead to breakthroughs in cancer therapy.

\section{Acknowledgements}

This study was supported by the "Funding Program for Next Generation World-Leading Researchers" from the Japan Society for the Promotion of Science (JSPS), by the "Program for the Promotion of Fundamental Studies in Health Science" from the National Institute of Biomedical Innovation (NIBIO), Japan, by Grants-in-aid for Scientific Research for Young Scientists (B) from the Ministry of Education, Culture, Sports, Science and Technology (MEXT), Japan, and by the Sagawa Foundation for the Promotion of Cancer Research.

\section{References}

Aebersold, D. M., Burri, P., Beer, K. T., Laissue, J., Djonov, V., Greiner, R. H., et al. (2001). Expression of hypoxia-inducible factor-1alpha: a novel predictive and prognostic parameter in the radiotherapy of oropharyngeal cancer. Cancer Res, 61(7), 29112916.

Batchelder, R. M., Wilson, W. R., Hay, M. P., \& Denny, W. A. (1996). Oxygen dependence of the cytotoxicity of the enediyne anti-tumour antibiotic esperamicin A1. Br J Cancer Suppl, 27, S52-56.

Berra, E., Roux, D., Richard, D. E., \& Pouyssegur, J. (2001). Hypoxia-inducible factor-1 alpha (HIF-1 alpha) escapes $\mathrm{O}(2)$-driven proteasomal degradation irrespective of its subcellular localization: nucleus or cytoplasm. EMBO Rep, 2(7), 615-620.

Bindra, R. S., Crosby, M. E., \& Glazer, P. M. (2007). Regulation of DNA repair in hypoxic cancer cells. Cancer Metastasis Rev, 26(2), 249-260. 
Binley, K., Askham, Z., Martin, L., Spearman, H., Day, D., Kingsman, S., et al. (2003). Hypoxia-mediated tumour targeting. Gene Ther, 10(7), 540-549.

Binley, K., Iqball, S., Kingsman, A., Kingsman, S., \& Naylor, S. (1999). An adenoviral vector regulated by hypoxia for the treatment of ischaemic disease and cancer. Gene Ther, 6(10), 1721-1727.

Boast, K., Binley, K., Iqball, S., Price, T., Spearman, H., Kingsman, S., et al. (1999). Characterization of physiologically regulated vectors for the treatment of ischemic disease. Hum Gene Ther, 10(13), 2197-2208.

Brizel, D. M., Scully, S. P., Harrelson, J. M., Layfield, L. J., Bean, J. M., Prosnitz, L. R., et al. (1996). Tumour oxygenation predicts for the likelihood of distant metastases in human soft tissue sarcoma. Cancer Res, 56(5), 941-943.

Brown, J. M. (1979). Evidence for acutely hypoxic cells in mouse tumours, and a possible mechanism of reoxygenation. Br J Radiol, 52(620), 650-656.

Brown, J. M., \& Wilson, W. R. (2004). Exploiting tumour hypoxia in cancer treatment. Nat Rev Cancer, 4(6), 437-447.

Chan, D. A., \& Giaccia, A. J. (2007). Hypoxia, gene expression, and metastasis. Cancer Metastasis Rev, 26(2), 333-339.

Chan, N., Koritzinsky, M., Zhao, H., Bindra, R., Glazer, P. M., Powell, S., et al. (2008). Chronic hypoxia decreases synthesis of homologous recombination proteins to offset chemoresistance and radioresistance. Cancer Res, 68(2), 605-614.

Comerford, K. M., Wallace, T. J., Karhausen, J., Louis, N. A., Montalto, M. C., \& Colgan, S. P. (2002). Hypoxia-inducible factor-1-dependent regulation of the multidrug resistance (MDR1) gene. Cancer Res, 62(12), 3387-3394.

Dachs, G. U., Dougherty, G. J., Stratford, I. J., \& Chaplin, D. J. (1997). Targeting gene therapy to cancer: a review. Oncol Res, 9(6-7), 313-325.

Dachs, G. U., Patterson, A. V., Firth, J. D., Ratcliffe, P. J., Townsend, K. M., Stratford, I. J., et al. (1997). Targeting gene expression to hypoxic tumour cells. Nat Med, 3(5), 515520.

Durand, R. E. (1994). The influence of microenvironmental factors during cancer therapy. In Vivo, 8(5), 691-702.

Erler, J. T., Bennewith, K. L., Nicolau, M., Dornhofer, N., Kong, C., Le, Q. T., et al. (2006). Lysyl oxidase is essential for hypoxia-induced metastasis. Nature, 440(7088), $1222-$ 1226.

Folkman, J. (1971). Tumour angiogenesis: therapeutic implications. N Engl J Med, 285(21), 1182-1186.

Forsythe, J. A., Jiang, B. H., Iyer, N. V., Agani, F., Leung, S. W., Koos, R. D., et al. (1996). Activation of vascular endothelial growth factor gene transcription by hypoxiainducible factor 1. Mol Cell Biol, 16(9), 4604-4613.

Fukuda, R., Zhang, H., Kim, J. W., Shimoda, L., Dang, C. V., \& Semenza, G. L. (2007). HIF-1 regulates cytochrome oxidase subunits to optimize efficiency of respiration in hypoxic cells. Cell, 129(1), 111-122.

Greco, O., Marples, B., Joiner, M. C., \& Scott, S. D. (2003). How to overcome (and exploit) tumour hypoxia for targeted gene therapy. J Cell Physiol, 197(3), 312-325.

Hall, E. J. (Ed.). (1994). Radiobiology for the Radiologists, Fourth Edition. Philadelphia: J.B. Lippincott Company.

Hanahan, D., \& Weinberg, R. A. (2000). The hallmarks of cancer. Cell, 100(1), 57-70.

Harada, H., \& Hiraoka, M. (2010). Hypoxia-inducible factor 1 in tumour radioresistance. Current Signal Transduction Therapy, 5, 188-196. 
Harada, H., Itasaka, S., Zhu, Y., Zeng, L., Xie, X., Morinibu, A., et al. (2009). Treatment regimen determines whether an HIF-1 inhibitor enhances or inhibits the effect of radiation therapy. Br J Cancer, 100(5), 747-757.

Harada, H., Kizaka-Kondoh, S., \& Hiraoka, M. (2005). Optical imaging of tumour hypoxia and evaluation of efficacy of a hypoxia-targeting drug in living animals. Mol Imaging, 4(3), 182-193.

Harada, H., Kizaka-Kondoh, S., Itasaka, S., Shibuya, K., Morinibu, A., Shinomiya, K., et al. (2007). The combination of hypoxia-response enhancers and an oxygen-dependent proteolytic motif enables real-time imaging of absolute HIF-1 activity in tumour xenografts. Biochem Biophys Res Commun, 360(4), 791-796.

Harris, A. L. (2002). Hypoxia--a key regulatory factor in tumour growth. Nat Rev Cancer, $2(1), 38-47$.

Hernandez-Alcoceba, R., Pihalja, M., Qian, D., \& Clarke, M. F. (2002). New oncolytic adenoviruses with hypoxia- and estrogen receptor-regulated replication. Hum Gene Ther, 13(14), 1737-1750.

Hicks, K. O., Pruijn, F. B., Secomb, T. W., Hay, M. P., Hsu, R., Brown, J. M., et al. (2006). Use of three-dimensional tissue cultures to model extravascular transport and predict in vivo activity of hypoxia-targeted anticancer drugs. J Natl Cancer Inst, 98(16), 11181128.

Hirota, K., \& Semenza, G. L. (2005). Regulation of hypoxia-inducible factor 1 by prolyl and asparaginyl hydroxylases. Biochem Biophys Res Commun, 338(1), 610-616.

Irie, N., Matsuo, T., \& Nagata, I. (2004). Protocol of radiotherapy for glioblastoma according to the expression of HIF-1. Brain Tumour Pathol, 21(1), 1-6.

Ishikawa, H., Sakurai, H., Hasegawa, M., Mitsuhashi, N., Takahashi, M., Masuda, N., et al. (2004). Expression of hypoxic-inducible factor 1alpha predicts metastasis-free survival after radiation therapy alone in stage IIIB cervical squamous cell carcinoma. Int J Radiat Oncol Biol Phys, 60(2), 513-521.

Jaakkola, P., Mole, D. R., Tian, Y. M., Wilson, M. I., Gielbert, J., Gaskell, S. J., et al. (2001). Targeting of HIF-alpha to the von Hippel-Lindau ubiquitylation complex by O2regulated prolyl hydroxylation. Science, 292(5516), 468-472.

Kaliberov, S. A., Buchsbaum, D. J., Gillespie, G. Y., Curiel, D. T., Arafat, W. O., Carpenter, M., et al. (2002). Adenovirus-mediated transfer of BAX driven by the vascular endothelial growth factor promoter induces apoptosis in lung cancer cells. Mol Ther, 6(2), 190-198.

Kim, J. W., Gao, P., \& Dang, C. V. (2007). Effects of hypoxia on tumour metabolism. Cancer Metastasis Rev, 26(2), 291-298.

Kizaka-Kondoh, S., Inoue, M., Harada, H., \& Hiraoka, M. (2003). Tumour hypoxia: a target for selective cancer therapy. Cancer Sci, 94(12), 1021-1028.

Liu, J., Harada, H., Ogura, M., Shibata, T., \& Hiraoka, M. (2007). Adenovirus-mediated hypoxia-targeting cytosine deaminase gene therapy enhances radiotherapy in tumour xenografts. Br J Cancer, 96(12), 1871-1878.

Liu, J., Qu, R., Ogura, M., Shibata, T., Harada, H., \& Hiraoka, M. (2005). Real-time imaging of hypoxia-inducible factor-1 activity in tumour xenografts. J Radiat Res (Tokyo), 46(1), 93-102.

Mahon, P. C., Hirota, K., \& Semenza, G. L. (2001). FIH-1: a novel protein that interacts with HIF-1alpha and VHL to mediate repression of HIF-1 transcriptional activity. Genes Dev, 15(20), 2675-2686. 
Maxwell, P. H., Wiesener, M. S., Chang, G. W., Clifford, S. C., Vaux, E. C., Cockman, M. E., et al. (1999). The tumour suppressor protein VHL targets hypoxia-inducible factors for oxygen-dependent proteolysis. Nature, 399(6733), 271-275.

Moeller, B. J., Cao, Y., Li, C. Y., \& Dewhirst, M. W. (2004). Radiation activates HIF-1 to regulate vascular radiosensitivity in tumours: role of reoxygenation, free radicals, and stress granules. Cancer Cell, 5(5), 429-441.

Moeller, B. J., Dreher, M. R., Rabbani, Z. N., Schroeder, T., Cao, Y., Li, C. Y., et al. (2005). Pleiotropic effects of HIF-1 blockade on tumour radiosensitivity. Cancer Cell, 8(2), 99-110.

Ogura, M., Shibata, T., Yi, J., Liu, J., Qu, R., Harada, H., et al. (2005). A tumour-specific gene therapy strategy targeting dysregulation of the VHL/HIF pathway in renal cell carcinomas. Cancer Sci, 96(5), 288-294.

Patterson, A. V., Williams, K. J., Cowen, R. L., Jaffar, M., Telfer, B. A., Saunders, M., et al. (2002). Oxygen-sensitive enzyme-prodrug gene therapy for the eradication of radiation-resistant solid tumours. Gene Ther, 9(14), 946-954.

Pennacchietti, S., Michieli, P., Galluzzo, M., Mazzone, M., Giordano, S., \& Comoglio, P. M. (2003). Hypoxia promotes invasive growth by transcriptional activation of the met protooncogene. Cancer Cell, 3(4), 347-361.

Post, D. E., \& Van Meir, E. G. (2003). A novel hypoxia-inducible factor (HIF) activated oncolytic adenovirus for cancer therapy. Oncogene, 22(14), 2065-2072.

Raleigh, J. A., Calkins-Adams, D. P., Rinker, L. H., Ballenger, C. A., Weissler, M. C., Fowler, W. C., Jr., et al. (1998). Hypoxia and vascular endothelial growth factor expression in human squamous cell carcinomas using pimonidazole as a hypoxia marker. Cancer Res, 58(17), 3765-3768.

Rinsch, C., Regulier, E., Deglon, N., Dalle, B., Beuzard, Y., \& Aebischer, P. (1997). A gene therapy approach to regulated delivery of erythropoietin as a function of oxygen tension. Hum Gene Ther, 8(16), 1881-1889.

Rofstad, E. K. (2000). Microenvironment-induced cancer metastasis. Int J Radiat Biol, 76(5), 589-605.

Semenza, G. L. (2001). HIF-1, O(2), and the 3 PHDs: how animal cells signal hypoxia to the nucleus. Cell, 107(1), 1-3.

Semenza, G. L. (2003). Targeting HIF-1 for cancer therapy. Nat Rev Cancer, 3(10), 721-732.

Semenza, G. L. (2007). Oxygen-dependent regulation of mitochondrial respiration by hypoxia-inducible factor 1 . Biochem J, 405(1), 1-9.

Semenza, G. L. (2008). Mitochondrial autophagy: life and breath of the cell. Autophagy, 4(4), 534-536.

Semenza, G. L. (2009). Regulation of cancer cell metabolism by hypoxia-inducible factor 1 . Semin Cancer Biol, 19(1), 12-16.

Shibata, T., Akiyama, N., Noda, M., Sasai, K., \& Hiraoka, M. (1998). Enhancement of gene expression under hypoxic conditions using fragments of the human vascular endothelial growth factor and the erythropoietin genes. Int J Radiat Oncol Biol Phys, 42(4), 913-916.

Shibata, T., Giaccia, A. J., \& Brown, J. M. (2000). Development of a hypoxia-responsive vector for tumour-specific gene therapy. Gene Ther, 7(6), 493-498.

Shibata, T., Giaccia, A. J., \& Brown, J. M. (2002). Hypoxia-inducible regulation of a prodrugactivating enzyme for tumour-specific gene therapy. Neoplasia, 4(1), 40-48.

Tannock, I. F. (1968). The relation between cell proliferation and the vascular system in a transplanted mouse mammary tumour. Br J Cancer, 22(2), 258-273. 
Tannock, I. F. (1998). Conventional cancer therapy: promise broken or promise delayed? Lancet, 351 Suppl 2, SII9-16.

Teicher, B. A. (1994). Hypoxia and drug resistance. Cancer Metastasis Rev, 13(2), 139-168.

Teicher, B. A., Lazo, J. S., \& Sartorelli, A. C. (1981). Classification of antineoplastic agents by their selective toxicities toward oxygenated and hypoxic tumour cells. Cancer Res, 41(1), 73-81.

Thomlinson, R. H., \& Gray, L. H. (1955). The histological structure of some human lung cancers and the possible implications for radiotherapy. Br J Cancer, 9(4), 539-549.

Vaupel, P., Kallinowski, F., \& Okunieff, P. (1989). Blood flow, oxygen and nutrient supply, and metabolic microenvironment of human tumours: a review. Cancer Res, 49(23), 6449-6465.

Wang, G. L., Jiang, B. H., Rue, E. A., \& Semenza, G. L. (1995). Hypoxia-inducible factor 1 is a basic-helix-loop-helix-PAS heterodimer regulated by cellular $\mathrm{O} 2$ tension. Proc Natl Acad Sci U S A, 92(12), 5510-5514.

Wartenberg, M., Ling, F. C., Muschen, M., Klein, F., Acker, H., Gassmann, M., et al. (2003). Regulation of the multidrug resistance transporter P-glycoprotein in multicellular tumour spheroids by hypoxia-inducible factor (HIF-1) and reactive oxygen species. FASEB J, 17(3), 503-505.

Wood, S. M., Wiesener, M. S., Yeates, K. M., Okada, N., Pugh, C. W., Maxwell, P. H., et al. (1998). Selection and analysis of a mutant cell line defective in the hypoxiainducible factor-1 alpha-subunit (HIF-1alpha). Characterization of hif-1alphadependent and -independent hypoxia-inducible gene expression. J Biol Chem, 273(14), 8360-8368.

Yang, M. H., Wu, M. Z., Chiou, S. H., Chen, P. M., Chang, S. Y., Liu, C. J., et al. (2008). Direct regulation of TWIST by HIF-1alpha promotes metastasis. Nat Cell Biol, 10(3), 295305.

Zeng, L., Ou, G., Itasaka, S., Harada, H., Xie, X., Shibuya, K., et al. (2008). TS-1 enhances the effect of radiotherapy by suppressing radiation-induced hypoxia-inducible factor-1 activation and inducing endothelial cell apoptosis. Cancer Sci, 99(11), 2327-2335.

Zhang, H., Bosch-Marce, M., Shimoda, L. A., Tan, Y. S., Baek, J. H., Wesley, J. B., et al. (2008). Mitochondrial autophagy is an HIF-1-dependent adaptive metabolic response to hypoxia. J Biol Chem, 283(16), 10892-10903.

Zhang, X., Kon, T., Wang, H., Li, F., Huang, Q., Rabbani, Z. N., et al. (2004). Enhancement of hypoxia-induced tumour cell death in vitro and radiation therapy in vivo by use of small interfering RNA targeted to hypoxia-inducible factor-1alpha. Cancer Res, 64(22), 8139-8142. 


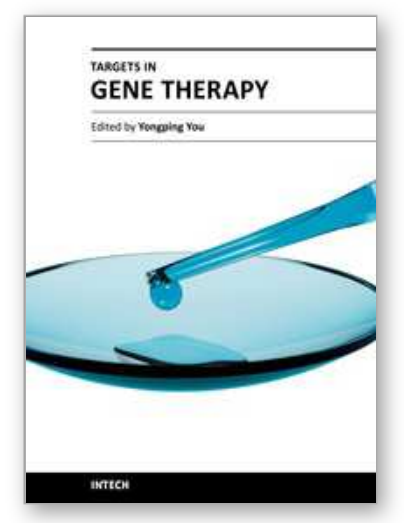

\author{
Targets in Gene Therapy \\ Edited by Prof. Yongping You
}

ISBN 978-953-307-540-2

Hard cover, 436 pages

Publisher InTech

Published online 23, August, 2011

Published in print edition August, 2011

This book aims at providing an up-to-date report to cover key aspects of existing problems in the emerging field of targets in gene therapy. With the contributions in various disciplines of gene therapy, the book brings together major approaches: Target Strategy in Gene Therapy, Gene Therapy of Cancer and Gene Therapy of Other Diseases. This source enables clinicians and researchers to select and effectively utilize new translational approaches in gene therapy and analyze the developments in target strategy in gene therapy.

\title{
How to reference
}

In order to correctly reference this scholarly work, feel free to copy and paste the following:

Hiroshi Harada (2011). Gene Therapy Strategy for Tumour Hypoxia, Targets in Gene Therapy, Prof. Yongping You (Ed.), ISBN: 978-953-307-540-2, InTech, Available from: http://www.intechopen.com/books/targets-ingene-therapy/gene-therapy-strategy-for-tumour-hypoxia

\section{INTECH}

open science | open minds

\author{
InTech Europe \\ University Campus STeP Ri \\ Slavka Krautzeka 83/A \\ 51000 Rijeka, Croatia \\ Phone: +385 (51) 770447 \\ Fax: +385 (51) 686166 \\ www.intechopen.com
}

\author{
InTech China \\ Unit 405, Office Block, Hotel Equatorial Shanghai \\ No.65, Yan An Road (West), Shanghai, 200040, China \\ 中国上海市延安西路65号上海国际贵都大饭店办公楼405单元 \\ Phone: +86-21-62489820 \\ Fax: +86-21-62489821
}


(C) 2011 The Author(s). Licensee IntechOpen. This chapter is distributed under the terms of the Creative Commons Attribution-NonCommercialShareAlike-3.0 License, which permits use, distribution and reproduction for non-commercial purposes, provided the original is properly cited and derivative works building on this content are distributed under the same license. 